\title{
On the origin and diversification of Venezuelan freshwater fishes: the genus Gephyrocharax (Ostariophysi: Characidae) a case study
}

\author{
Ana Bonilla-Rivero and Héctor López-Rojas
}

\begin{abstract}
We conducted a phylogeographic analysis of the genus Gephyrocharax in Venezuela to evaluate geomorphologic evidence for the formation of the country's main watersheds and to establish a biogeographical hypothesis of possible diversification mechanisms of the Neotropical freshwater fish fauna. We assayed eight enzyme systems and general proteins to estimate genetic variability $(H, P)$, intraspecific structuring in several Gephyrocharax valencia and G. venezuelae populations $\left(\mathrm{F}_{\text {IS }}, \mathrm{F}_{\text {IT }}\right.$, and $\mathrm{F}_{\mathrm{ST}}$ ), and a phylogenetic approach for the three species of Gephyrocharax in Venezuela, using Corynopoma riisei as the external group. Fourteen presumptive loci indicate that populations of the three species of Gephyrocharax analyzed show a clear genetic inter-specific differentiation, determined by four loci with fixed alleles (GPI-B*, IDH*, $M E-1^{*}$, and $\left.M E-2^{*}\right)$. The resulting cladogram shows two major clades: a monophyletic group consisting of Gephyrocharax n. sp. and G. venezuelae (restricted to the northwest of the country) and a group formed exclusively by G. valencia (distributed along the largest geographic range). Speciation of the Venezuelan lineages of the genus Gephyrocharax could be explained by the origin and course movements of the present Orinoco River together with geomorphologic processes that have occurred in northern Venezuela since the Miocene.
\end{abstract}

Foi feita uma análise filogeográfica do gênero Gephyrocharax na Venezuela a fim de avaliar as evidências geomorfológicas que levaram à formação dos principais sistemas hidrográficos do país, além de estabelecer uma hipótese biogeográfica com os possíveis mecanismos de diversificação da fauna de peixes de água doce Neotropical. Foram analisados oito sistemas enzimáticos e proteínas gerais para conhecer a variabilidade genética $(H, P)$, estruturação intraespecífica em populações de Gephyrocharax valencia e G. venezuelae $\left(\mathrm{F}_{\mathrm{IS}}, \mathrm{F}_{\mathrm{IT}} \mathrm{e} \mathrm{F}_{\mathrm{ST}}\right)$, e uma abordagem filogenética com base na análise isozimática para as três espécies de Gephyrocharax na Venezuela, com Corynopoma riisei como grupo externo. Quatorze loci presumíveis indicam que as populações das três espécies de Gephyrocharax analisados revelam uma diferenciação inter-específica genética, determinada por quatro loci com alelos fixos (GPI- $B^{*}, I D H^{*}, M E-1 *$ e $\left.M E-2 *\right)$. O cladograma resultante apresenta dois clados principais: um grupo monofilético composto por Gephyrocharax n. sp. e G. venezuelae (restrita ao noroeste do país) e um grupo formado exclusivamente por G. valencia (distribuídos ao longo da maior área geográfica). A especiação das linhagens de Gephyrocharax na Venezuela poderia ser explicada pela origem e movimentos do curso atual da bacia do rio Orinoco, associado a processos geomorfológicos que ocorrem no norte da Venezuela desde o Mioceno.

Key words: Isoenzymes, Speciation, Venezuela, Vicariance.

\section{Introduction}

The high diversity of tropical freshwater fishes has been mainly attributed to allopatric speciation with subsequent mixing given the appropriate physical conditions (LoweMcConnell, 1969). However, Lundberg et al. (1998) suggested that vicariant events produced by the movement and division of drainages in large rivers represented a significant source of diversification of neotropical freshwater fishes. Moreover, Lovejoy et al. (1998, 2006) suggested that marine transgressions during the Early Miocene (15-23 million years) profoundly affected the structure and diversification of neotropical fish communities and indicated that some species of South American freshwater fishes had originated from marine groups by means of massive movements of seawater into the upper Amazon region.

A Parsimony Analysis of Endemicity by Hubert \& Renno (2006) proposed that the establishment of the freshwater fish fauna of South America was the result of the interaction of various processes such as marine incursions, the elevation of mountain systems and historical connections that allowed dispersal between drainages. They emphasized the presence

Laboratorio de Ictiología, Centro MBUCV, Instituto de Zoología y Ecología Tropical, Facultad de Ciencias, Universidad Central de Venezuela, Caracas, Venezuela. ana.bonilla@ciens.ucv.ve 
of seven dispersion routes scattered throughout the Amazon, Orinoco, and Paraná rivers. In their review of the phylogenetic patterns of fishes of the rivers of northwestern South America, Albert et al. (2006) concluded that these patterns are highly consistent with geological information regarding the isolation time of these drainages. They also suggested that the species composition of these river basins was modern by the time the late Middle Miocene tectonics events occurred.

In recent studies of species differentiation it has become common to use a phylogenetic approach to integrate information on genetic and morphological differentiation and geographical distribution patterns, so as to establish a more robust hypothesis of their relationships (Avise et al., 1987; McKay \& Miller, 1991; Dimmick \& Lawson, 1991; Carmona et al., 2000; Pouyaud et al., 2000; Morris et al., 2001; Bonilla et al., 2002; Wang et al., 2004; Strecker et al., 2004; Salzburger et al., 2005). For example, Carmona et al. (2000) studied Chondrostoma lemmingii, a cyprinid endemic to the Iberian Peninsula, using genetic criteria (allozymes and cytochrome c) and determined that the phenetic and phylogenetic relationships found supported the hypothesis that the process of differentiation between their populations was due to several vicariant events including endorheism and hydrological isolation of the drainages studied. On the other hand, there are examples where geographical isolation does not lead to detectable genetic differentiation: Revaldaves et al. (1997) studied the isoenzyme variability of Prochilodus lineatus (Characidae) from three isolated localities of the Paraná River, Brazil, and found a relatively high average heterozygosity $(\mathrm{H}=13 \%)$ but a low level of differentiation $\left(\mathrm{F}_{\mathrm{ST}}=0.018\right)$ between the populations studied.

There are many freshwater fishes suitable for studying the influence of vicariant fractioning on isolated populations, in particular, species of the genus Gephyrocharax (Characidae, Stevardiinae; Weismann et al., 2005) that present a predominantly allopatric geographical distribution in South and Central America (Fig. 1A). In Venezuela three species have been described: Gephyrocharax valencia was originally described from Lake Valencia in north-central Venezuela, but is widely distributed throughout the Orinoco River basin, as well as in the Tocuyo, Aroa, Yaracuy, Urama, San Esteban, and Neverí rivers, all draining into the Caribbean Basin. $G$. venezuelae is restricted to Lake Maracaibo (Schultz, 1944) and the western Caribe Basin: Cueva del Indio, Cuare (Falcón) (López et al., 1996), Urama River (Bonilla \& López, 2001), Aroa, Yaracuy and Tocuyo rivers (Rodríguez et al., 2006). The Urama River forms the eastern boundary of $G$. venezuelae in the entire Caribe Basin. The taxonomic identity of a third venezuelan species of Gephyrocharax, identified by several authors as G. melanocheir deserves a separate consideration as its characteristics do not coincide with any of the valid species described for Venezuela (Eigenmann, 1912; Schultz, 1944; Dahl, 1971). Differences in color pattern suggest it could be a new species, and consequently will be referred to in this manuscript as Gephyrocharax n. sp. It will be described in a separate paper in preparation. Gephyrocharax n. sp. has been reported only in some drainages in Zulia (Taphorn \& Lilyestrom, 1984) and Falcón States (Sierra de San Luis; J. Moscó, unpublished data) belonging to Venezuela's western Caribe basin. Despite the coincidental distribution of $G$. venezuelae and Gephyrocharax n. sp. in the Lake Maracaibo and Caribe basins, so far these two species have not been found sympatrically. G. valencia and G. venezuelae, on the other hand, are sympatric in drainages of the Caribe Basin between the Tocuyo and Urama rivers.

The main objective of this study was to conduct an isoenzymatic analysis of the species of the genus Gephyrocharax in Venezuela to compare the information obtained with geomorphological evidence for the formation of the major watersheds in the country. The resulting biogeographic hypothesis could be used as a model to explain the potential mechanisms involved in the diversification of the country's freshwater fish fauna.

\section{Material and Methods}

Specimens studied are representative of allopatric populations of the three species of the genus Gephyrocharax; additionally, two sympatric populations of G. valencia and $G$. venezuelae from the Aroa and Taría rivers are included (populations 3 and 4; Fig. 1b). The population of Corynopoma riisei (population 6, Fig. 1b) used as the external group is allopatric with respect to those of Gephyrocharax.

Material examined. Gephyrocharax valencia, MBUCV-V-35679, 15, 18.3-24.3 mm SL, río Aroa, Falcón, km 26 vía Palma Sola-Boca de Aroa, 10³8'02'N 68²8'01'W.; río Las Peñas de Taría, Yaracuy, afluente del río Yaracuy, $8 \mathrm{~km}$ pasando el pueblo Taría, $10^{\circ} 22.6^{\prime} \mathrm{N}$ $68^{\circ} 32.9^{\prime} \mathrm{W}, \mathrm{MBUCV}-\mathrm{V}-35682$, 17, 17.8-22.4 mm SL; río Guapo, Miranda, antes de llegar a la planta de tratamiento vía represa El Guamito, MBUCV-V-35683, 20, 20.9-33.5 mm SL; río Pao, Anzoátegui, MBUCV-V- 35684, 11, 22.7-34.2 mm SL. Gephyrocharax venezuelae: río La Pedregosa, Zulia, afluente del río Machango, cruce de la carretera desde el pueblo de Sipayare, $10^{\circ} 09.321^{\prime} \mathrm{N} 70^{\circ} 53.841^{\prime} \mathrm{W}, \mathrm{MBUCV}-\mathrm{V}-35685$, 7, 25.0-37.4 mm SL; río Aroa, Falcón, km 26, vía Palma Sola-Boca de Aroa, 10³8'2" N 68²8'1"W, MBUCV-V- 35686, 7, 27.2-30.5 mm SL; río Las Peñas de Taría, Yaracuy, afluente del río Yaracuy, $8 \mathrm{~km}$ pasando el pueblo Taría, 10²2.6' N 68³2.9' W, MBUCV-V-35687, 39, 22.829.9 mm SL; río Alpargatón, Carabobo, cantera, MBUCV-V-35688, 31, 30.9-22.9 mm SL. Gephyrocharax sp.n.?: río Meachiche, Falcón, balneario Meachiche, MBUCV-V-35689, 19, 31.5-38.1 mm SL. Corynopoma riisei: río La Cumaca, Carabobo, afluente del río San Diego, entrando por la Urbanización Villas de San Diego, sector La Cumaca, San Diego, MBUCV-V-35690, 9, 29.2-39.00 mm SL.

For the genetic analysis skeletal muscle was homogenized with buffer Tris/0.001 M 0.1 M EDTA pH 7.0 and analyzed by $10 \%$ starch gel electrophoresis in a horizontal system. Gels were prepared following a modification of the microwave cooking method described in Murphy et al. (1990): gels were cooked for 12 minutes with manual agitation every 30 seconds until they thickened, then were allowed to boil and degasified with a vacuum pump. We assayed 8 specific enzymes and 

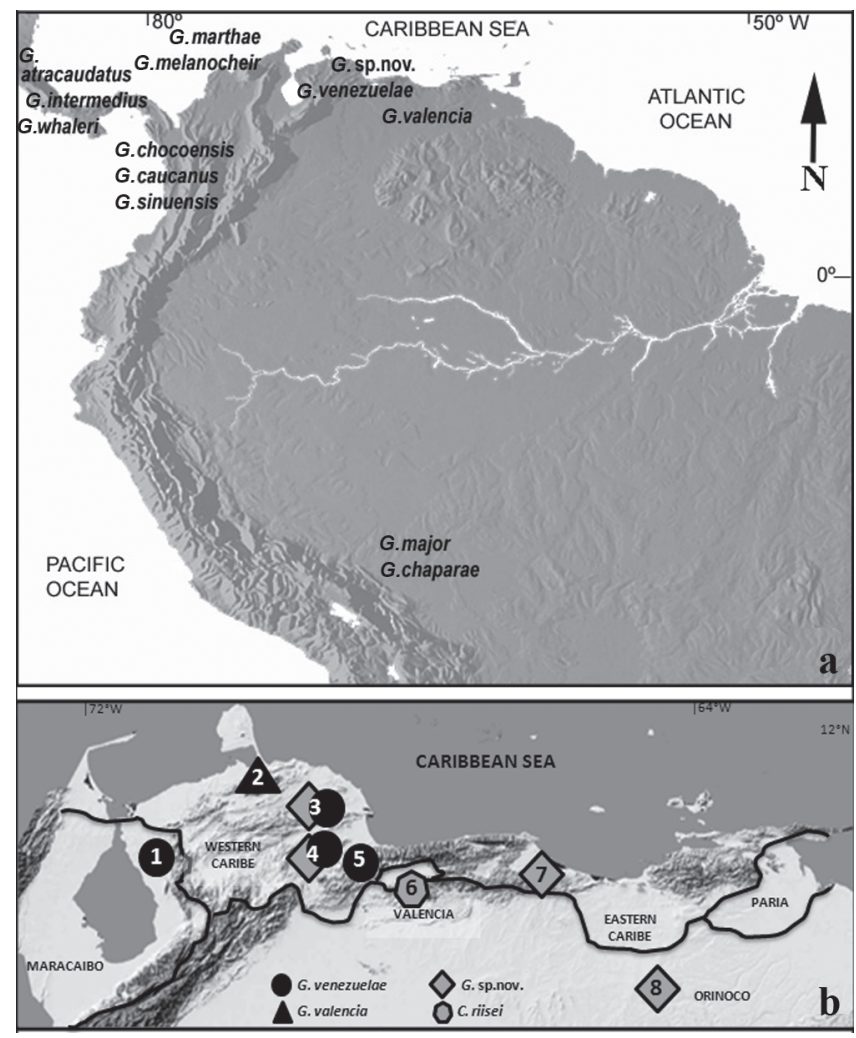

Fig. 1. a. Geographical distribution of species of Gephyrocharax. b. Sampling sites for Gephyrocharax and Corynopoma riisei in Venezuela. 1. La Pedregosa River, Machango River basin, Zulia State. 2. Meachiche River, Falcón State. 3. Aroa River, km 26, Palma Sola, Falcón State. 4. Las Peñas de Taría River, Yaracuy River basin, Yaracuy State. 5. Alpargatón River, Urama River basin, Carabobo State. 6. La Cumaca River, San Diego River basin, Carabobo State. 7. La Maleja creek, Guapo River basin, Miranda State. 8. Pao River, Orinoco River basin, Anzoátegui State. In sites 3 and 4 G. venezuelae and G. valencia occur sympatrically. Limits between major river basins (Lake Maracaibo, Caribe, Paria, and Orinoco) follow Mago-Leccia (1970) and are indicated with a solid line.

general proteins with five different electrophoretic buffers; details of the enzyme systems more fully revealed and electrophoretic conditions are listed in Table 1. Nomenclature of presumptive loci, as well as their corresponding alleles, follow Shaklee et al. (1990) for electrophoretic studies in fish. Data analysis was performed using BIOSYS-1 (Swofford \& Selander, 1981) to determine allelic frequencies, percentage of polymorphic loci $(P)$, average heterozygosity $(H)$, and deviations from the Hardy-Weinberg equilibrium for each polymorphic locus in each population analyzed, using Levene's correction for small sample size. Addititionally, we calculated the statistics $\mathrm{F}_{\mathrm{IS}}, \mathrm{F}_{\mathrm{IT}}$, and $\mathrm{F}_{\mathrm{ST}}$ to determine intraspecific structuring in $G$. valencia and $G$. venezuelae. The statistic $\mathrm{F}$ was also calculated for a pool of the three species so as to determine the levels of interspecific differentiation. No calculations for population structure were made for Gephyrocharax n. sp. as we were only able to sample one single population (population 2; Fig.1b). Using a hierarchical geographical array analysis the genetic distance coefficient (Cavalli-Sforza \& Edwards, 1967 arc distance, D) and level of population structure (F) statistics (Wright, 1978) were calculated for G. valencia and G. venezuelae to determine the differences between: 1. Western (populations 1, 3, 4 and 5; Fig. 1b) and Eastern (populations 7 and 8; Fig. 1b) REGIONS compared to the TOTAL $\left(\mathrm{F}_{\mathrm{RT}}\right) ; 2$. Populations within each Region $\left(\mathrm{F}_{\mathrm{PR}}\right)$; 3. Basins compared to the Total $\left(\mathrm{F}_{\mathrm{BT}}\right)$; and 4. All Populations in relation to the Total $\left(\mathrm{F}_{\mathrm{PT}}\right)$. In the latter case the value of $\mathrm{F}_{\mathrm{PT}}$ represents an estimate of population structure equivalent to the statistic $\mathrm{F}_{\mathrm{ST}}$. The product between the effective population size $\left(\mathrm{N}_{\mathrm{e}}\right)$ and the rate of gene flow $(\mathrm{m})$ was used as an estimator of the extent of genetic structuring between the populations studied $\left(\mathrm{N}_{\mathrm{e}} \mathrm{m}\right)$, using the formula $\mathrm{F}_{\mathrm{ST}}$ $=1 / 1+4 \mathrm{~N}_{\mathrm{e}} \mathrm{m}$ (Wright, 1931). Values of $\mathrm{Ne}_{\mathrm{e}} \mathrm{m}>1$ indicate lack of migrant interchanges that could prevent differentiation due to genetic drift (Slatkin 1985); i.e., due to a high gene flow there is no genetic structure in the population.

The most parsimonious tree was calculated with the Wagner Distance method using the Cavalli-Sforza \& Edwards (1967) arc distance index. This index has been reported as the most appropriate to derive phylogenetic trees from allelic 
Table 1. Enzyme systems studied, enzyme commission code number, buffer and running conditions, reference, and loci scored for Gephyrocharax and Corynopoma species.

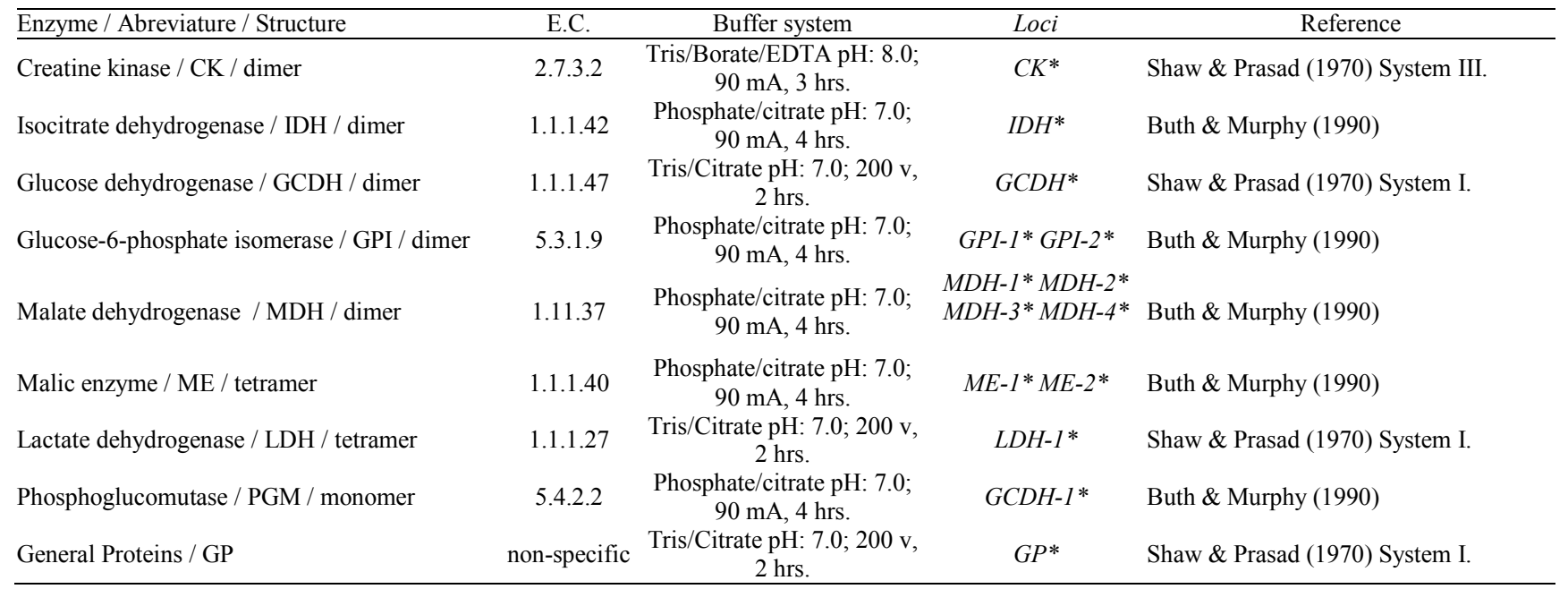

frequency data (Roger, 1986). Corynopoma riisei, a species of the tribe Corynopomini, which includes Gephyrocharax, Corynopoma, and Pterobrycon (Weitzman \& Menezes, 1998), was used as an external group. The results of the hierarchical genetic analysis were reviewed in conjunction with the geomorphological information available for northwestern South America (Lundberg et al., 1998; Albert et al., 2006) and Venezuela (Rod, 1981; Mendez, 1985; Díaz de Gamero, 1996) in order to offer further biogeographical evidence for the probable vicariant origin of the Orinoco, Lake Maracaibo, and Caribe basins.

\section{Results}

Eight enzyme systems and the general proteins (GP) showed well-defined bands that allowed us to establish iso and aloenzymatic patterns for 14 presumptive loci. Loci GPI$A^{*}$ and $P G M^{*}$ were polymorphic $\left(100^{*}\right.$ allele with a frequency of less than 0.990) in at least one of the populations of each species studied, while loci $C K^{*}, G C D H^{*}, G P-1^{*}, G P I-B^{*}$, $I D H^{*}, L D H-A^{*}, M D H-1^{*}, M D H-2^{*}, M D H-3^{*}, M D H-4^{*}, M E-$ $1 *$, and $M E-2 *$ were monomorphic. However four of them (GPI- $B^{*}, I D H^{*}, M E-1^{*}$, and $\left.M E-2^{*}\right)$ had different mobilities between species and/or between populations of the same species (Table 2). Because of their fixed allelic differences these may represent diagnostic loci between species of Gephyrocharax, and between Gephyrocharax and Corynopoma. For example, GPI- $B^{*}$ differentiates Corynopoma riisei from the three species of Gephyrocharax studied; $I D H^{*}$ differentiates G. valencia and Gephyrocharax n. sp. from $G$. venezuelae and $C$. riisei; $M E-1^{*}$ and $M E-2^{*}$ differentiate $G$. valencia and C. riisei from G. venezuelae and Gephyrocharax n. sp.

Genetic variability, expressed as the proportion of polymorphic loci $(P)$ and average frequency of heterozygotic loci for individuals for each population analyzed are shown in Table 2. $P$ values for the Gephyrocharax populations studied varied between 7.1 and $14.3 \%$ with two polymorphic loci: GPI-A* and PGM*. Polymorphism level for the Corynopoma riisei population was $0.00 \%$. $H$ values were low and very similar for all populations studied. In populations of G. venezuelae and Gephyrocharax n. sp. $H$ values were higher than those of populations of $G$. valencia and $C$. riisei, albeit with a very low level of differentiation. The $\chi^{2}$ test showed with a $99 \%$ confidence level that the locus GPI-A* in six out of nine populations of Gephyrocharax studied were not in accordance with the Hardy-Weinberg law. All populations, except La Pedregosa, revealed a clear heterozygosity deficiency for the GPI-A* locus with negative values of the parameter $\mathrm{D}$ equal to minus one $(-1.000)$ or very close to this maximum value. Results for the fixation index $(F)$ show a high degree of inbreeding for these populations with maximum values (1.000) of this parameter in all populations, except for the population of G. venezuelae from La Pedregosa River, with a value of the statistic $\mathrm{F}$ equal to -0.077 . The $P G M^{*}$ locus deviated significantly from the Hardy-Weinberg equilibrium in two populations of $G$ valencia: Aroa y Taría (Table 2).

Interspecific comparisons (Cavalli-Sforza \& Edwards, 1967 arc distance index) resulted in a closer genetic proximity between G. venezuelae and Gephyrocharax n. sp. $(\mathrm{D}=0.371$ [0.359-0.377]), whereas the most dissimilar species were $G$. valencia and $G$. venezuelae $(\mathrm{D}=0.537[0.517-0.556])$. Distance values for Corynopoma riisei and the Gephyrocharax species were $0.470,0.484$, and 0.593 for $G$. venezuelae, $G$. valencia, and Gephyrocharax n. sp., respectively (Table 3). The level of genetic differentiation among the three species of Gephyrocharax in Venezuela is within the average range for full species (Nei, 1975). A high average value $\left(\mathrm{F}_{\text {IS }}=0.703\right.$; $\mathrm{F}_{\mathrm{IT}}=0.952 ; \mathrm{F}_{\mathrm{ST}}=0.839$ ) of the Wright $\mathrm{F}$ statistic indicates a clear genetic differentiation among the species of 
Table 2. Allelic frequencies, heterozygosity per locus ( $h$; unbiased estimation according to Nei, 1978) for the polymorphic locus and the diagnostic loci in the Gephyrocharax and Corynopoma populations studied. (N) number of individuals studied, $(P)$ percentage of polymorphism, $(H)$ average heterozygosity (standard errors in parentheses), (Obs) heterozygotes observed, (Esp) heterozygotes expected, $\left(\chi^{2}\right)$ chi squared, $(D)$ heterozygote deficiency coefficient, $(F)$ fixation index, $\left(\mathrm{F}_{\mathrm{ST}}\right)$ population differentiation coefficient. ${ }^{(1)}$ Negative values indicate heterozygote deficiency. ${ }^{(2)}$ Direct-count. A locus is considered polymorphic if the frequency of the most common allele $(* 100)$ is lower than $0.990 .{ }^{(3)}$ significative with a $99 \%$ confidence.

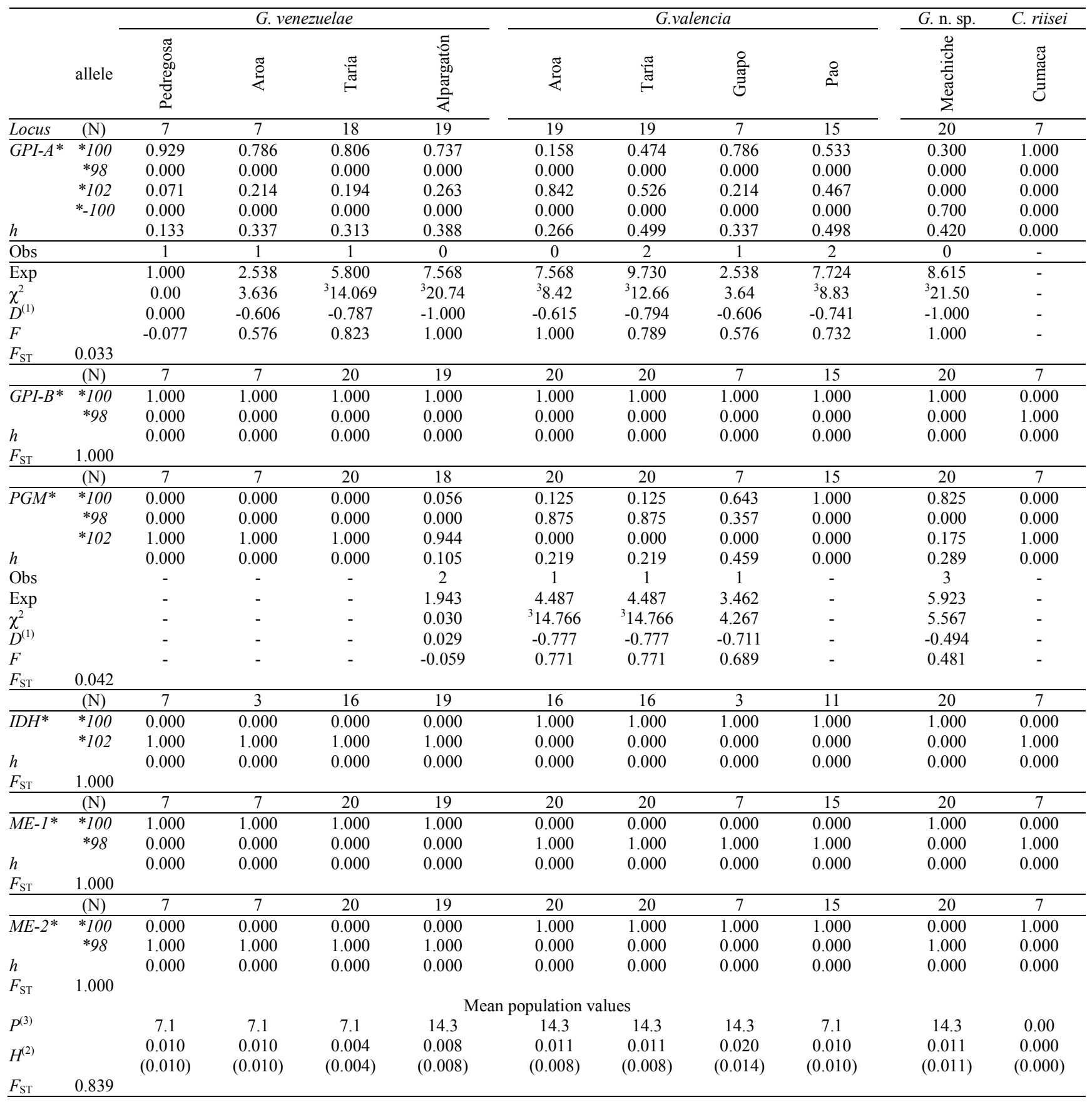

Gephyrocharax. These values are determined mainly by the maximum contribution $\left(\mathrm{F}_{\mathrm{ST}}=1.000\right)$ of the $G P I-2^{*}, I D H^{*}, M E-$ $I^{*}$, and $M E-2 * l o c i$, which could be regarded as diagnostic loci for the differentiation of the three species.
A hierarchical analysis of genetic distances using the Cavalli-Sforza \& Edwards (1967) arc distance index between the three species of Gephyrocharax studied showed differentiation across the three major river basins sampled. 
Table 3. Cavalli-Sforza \& Edwards (1967) arc distance index for the Gephyrocharax and Corynopoma populations studied.

\begin{tabular}{|c|c|c|c|c|c|c|c|c|c|c|c|}
\hline \multirow[b]{3}{*}{1} & \multirow[b]{3}{*}{ G.venezuelae Pedregosa } & \multicolumn{10}{|c|}{ Population } \\
\hline & & 1 & 2 & 3 & 4 & 5 & 6 & 7 & 8 & 9 & 10 \\
\hline & & - & 0.036 & 0.032 & 0.061 & 0.556 & 0.542 & 536 & 0.541 & 0.373 & 0.465 \\
\hline 2 & G. venezuelae Aroa & & - & 0.004 & 0.042 & 0.547 & 0.537 & 0.535 & 0.537 & 0.377 & 0.470 \\
\hline 3 & G. venezuelae Taría & & & - & 0.043 & 0.548 & 0.538 & 0.535 & 0.537 & 0.376 & 0.469 \\
\hline 4 & G. venezuelae Alpargatón & & & & - & 0.538 & 0.530 & 0.519 & 0.517 & 0.359 & 0.474 \\
\hline 5 & G. valencia Aroa & & & & & - & 0.060 & 0.151 & 0.217 & 0.490 & 0.503 \\
\hline 6 & G. valencia Taría & & & & & & - & 0.112 & 0.206 & 0.478 & 0.483 \\
\hline 7 & G. valencia Guapo & & & & & & & - & 0.118 & 0.438 & 0.470 \\
\hline 8 & G. valencia Рao & & & & & & & & - & 0.433 & 0.480 \\
\hline 9 & G. sp.nov. Meachiche & & & & & & & & & - & 0.593 \\
\hline 10 & C. riisei Cumaca & & & & & & & & & & - \\
\hline
\end{tabular}

Most different were populations from the Orinoco and Maracaibo basins $(D=0.541$ [0.541-0.541]); populations from the Caribe and Orinoco basins are genetically closer to each other $(D=0.366[0.118-0.537])$, as are those of the Caribe and Maracaibo basins $(D=0.305[0.032-0.556])$. Results from the hierarchical intraspecific analysis showed that G. valencia populations were genetically more differentiated $(D=0.144$ $[0.060-0.217])$ than $G$. venezuelae populations $(D=0.036[0.004-$ $0.061])$. Hierarchical genetic analyses of $G$. valencia and $G$. venezuelae revealed differences in the level and extent of the structuring of the populations studied (Table 4). G. valencia showed evidence of interpopulation differentiation and low genetic flow between populations of the western and eastern regions as well as between those of the Caribe and Orinoco basins, and between all populations with respect to the total; nevertheless populations within each region were relatively homogeneous. For G. venezuelae the structure level was very low for all hierarchical levels compared and with gene flow values corresponding to those of connected populations (Wright, 1943).

A phylogenetic approach based on isoenzyme analysis for the three species of Gephyrocharax in Venezuela yielded the most parsimonious cladogram using Cavalli-Sforza \& Edwards (1967) arc distance index (Fig. 2). The tree was rooted using Corynopoma riisei as the external group. The resulting cladogram shows a well-defined group with two major clades: a monophyletic group (a) consisting of Gephyrocharax n.

Table 4. Variance components and hierarchical F statistics for all loci of $G$. venezuelae and G. valencia. Negative values are considered non-defined and are the result of higher intrapopulation (as opposed to inter-population) variability (Lessios et al., 1998).

\begin{tabular}{lcccccc}
\hline & \multicolumn{6}{c}{ Species } \\
\cline { 2 - 7 } $\begin{array}{c}\text { Comparison } \\
\text { level }\end{array}$ & \multicolumn{3}{c}{ G. venezuelae } \\
\hline & Variance & $\mathrm{F}_{\mathrm{XY}}$ & $\mathrm{N}_{\mathrm{e}} \mathrm{m}$ & Variance & $\mathrm{F}_{\mathrm{XY}}$ & $\mathrm{N}_{\mathrm{e}} \mathrm{m}$ \\
$\mathrm{F}_{\mathrm{RT}}$ & 0.00903 & -0.020 & - & 0.20596 & 0.206 & 0.96 \\
$\mathrm{~F}_{\mathrm{PR}}$ & -0.00213 & 0.052 & 4.56 & 0.15317 & 0.193 & 1.05 \\
$\mathrm{~F}_{\mathrm{BT}}$ & 0.00146 & 0.033 & 7.33 & 0.27460 & 0.275 & 0.66 \\
$\mathrm{~F}_{\mathrm{PT}}$ & 0.00689 & 0.033 & 7.33 & 0.35913 & 0.360 & 0.44 \\
\hline
\end{tabular}

sp. and G. venezuelae and a group (b) formed exclusively by G. valencia. The latter is distributed along the largest geographic range while the most distant species from the external group, Gephyrocharax n. sp. and G. venezuelae, are geographically restricted to the northwest of the country. In the cladogram obtained all nodes are fully resolved, except for the populations of G. venezuelae from the Taría and Aroa rivers which cannot be distinguished from the loci revealed in this study.

\section{Discussion}

In this study we selected populations of the three species of Gephyrocharax distributed in different watersheds under conditions of sympatry and allopatry. Analyses of differentiation and genetic distances were performed using a hierarchical approach. This is important when dealing with data from different populations belonging to different species in different geographic areas, because it allows for the evaluation of intra and inter-specific variability in a geographical context (Trexler, 1988; Johnson, 2001).

The Gephyrocharax species studied showed a clear interspecific genetic differentiation determined by the presence of four different loci with fixed alleles $\left(G P I-B^{*}, I D H^{*}, M E-1^{*}\right.$, and $M E-2 *$ ) together with conditions of very high inbreeding. Regarding the geographical relationships between basins, the hierarchical analysis showed greater genetic affinity between the eastern Caribe and Orinoco basins, and between the western Caribe and Maracaibo basins, probably as a consequence of a longer isolation period between the Lake Maracaibo and Orinoco basins than that between the Caribe and Orinoco basins, mainly in the eastern region of the country. Evaluation of gene flow $\left(\mathrm{N}_{\mathrm{e}} \mathrm{m}\right)$ indicated that populations of $G$. venezuelae retain connections and that the small differences observed could represent a case of independent evolution under strong selective pressures. In the case of G. valencia, there is clear evidence for isolation between the eastern and western populations, whose $\mathrm{N}_{\mathrm{e}} \mathrm{m}$ values denote a low level of gene flow between disconnected populations, possibly due to the differentiation of neutral alleles. Significantly, western populations of G. valencia sampled are found in the Caribe basin, whereas eastern populations of the same species are distributed both in 


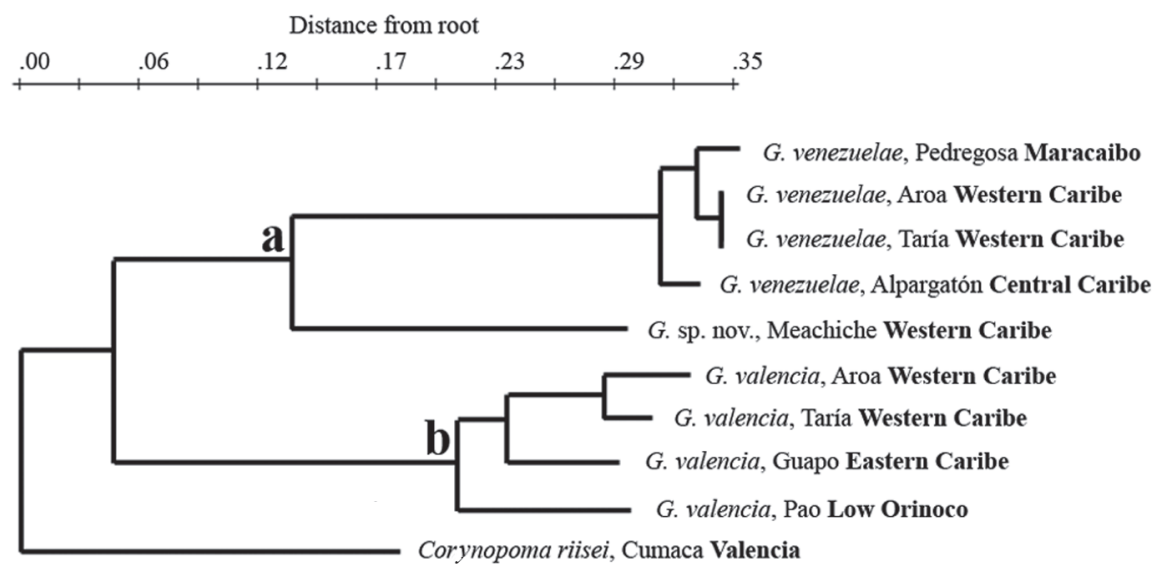

Fig. 2. Phylogenetic approach for the three species of Gephyrocharax in Venezuela. Corynopoma riisei is included as the external group (Names in bold denote major river basins referred to in the text).

Venezuela's Caribe and Orinoco basins, which are more than $500 \mathrm{~km}$ apart. By contrast, the value of $\mathrm{N}_{\mathrm{e}} \mathrm{m}$ for G. venezuelae indicates a trend towards panmixia within each region, possibly due to the more recent connections maintained by the rivers analyzed within each region and their geographical proximity.

In Venezuela, a succession of geologic events coupled with different water divisions, largely related to the Orinoco River basin, has determined the formation of the country's watersheds. Fig. 3 schematically represents a proposal for the possible origin and diversification of species of the genus Gephyrocharax in Venezuela, taking into consideration the formation of the major river basins and a phylogenetic analysis based on isoenzyme characters. Within clade (a), Gephyrocharax n. sp. + G. venezuelae (Fig. 2), populations of G. venezuelae analyzed are distinct: the population of Alpargatón (Carabobo State) is the sister group of populations from Taría-Aroa-Pedregosa (Yaracuy-Falcón-Zulia States). The species $G$. venezuelae probably originated via vicariant allopatric speciation (Bush, 1975) as a consequence of the splitting of the watershed of the current Magdalena River (Colombia) and the Proto-Orinoco River (11.8-10 Ma) (Lundberg et al., 1998; Albert et al., 2006). Remnant populations are found in the present-day Lake Maracaibo region as well as in Falcón and Yaracuy States. Subsequent isolation of the Maracaibo and Falcón basins (approximately between 2 to $1 \mathrm{My}$.; Yoris \& Ostos, 1997) causes the distribution of G. venezuelae to become disjunct as the mountains that form the Falcón-Lara-Yaracuy cordillera rise to their current state; this is evidenced by the presence of $G$. venezuelae in the Lake Maracaibo basin and in the drainages of the depression that was formed between the mountains of Falcón-Lara-Yaracuy and Cordillera de la Costa (Fig. 3).

The continental relief of the Lara-Falcón-Yaracuy region is characterized by the presence of hills oriented in a general east-west direction, except for the Siruma Sierra, which has a north-south orientation and is closer to Zulia State. It should be noted that the Aroa-Taría group is the most inclusive, its localities being more closely together in the geographical distribution range of $G$. venezuelae examined in this work. In this respect, the populations of $G$. venezuelae studied come from rivers that are currently in the region covering the ancient Proto-Orinoco delta, which extended from the Maracaibo Depression to the western limit of the Cordillera de la Costa (Zulia, Falcón, and Carabobo States). Upon the definitive rise of the Lara-Falcón-Yaracuy Sierra some waterways in lowland drainages became elevated to mountainous areas with a consequent change in their environmental conditions. This change may have fostered or molded changes in the genetic structure of the populations of fishes in these mountain rivers, as opposed to the fish populations of those rivers that were not affected by major environmental changes. Among those mountain rivers are the Taría and Aroa, whereas the Alpargatón and Pedregosa rivers are in lowland areas. The current geomorphological configuration of the Falcón State region probably caused the emergence via vicariance of a more recent lineage, Gephyrocharax n. sp., distributed in the small rivers originating in the mountains to the north and draining directly into the Caribbean Sea. The presence of Gephyrocharax n. sp. is associated with more recent geological formations (Pliocene; PDVSA, 2008) as opposed to those where G. venezuelae occur (Middle to Late Miocene; PDVSA, 2008).

Clade b (G. valencia) also shows structuring for the populations studied: the groups of Venezuela's western Caribe basin (Taría-Aroa) are related among themselves and form the sister group of the clade Guapo + Pao (Venezuela's eastern Caribe-Orinoco basins) with the Guapo population from the eastern Caribe basin as its sister group and the population of Pao (Orinoco) as the basal group of G. valencia.

Subsequent changes to the Orinoco River course, in which the Maracaibo and Falcón basins became isolated, would 


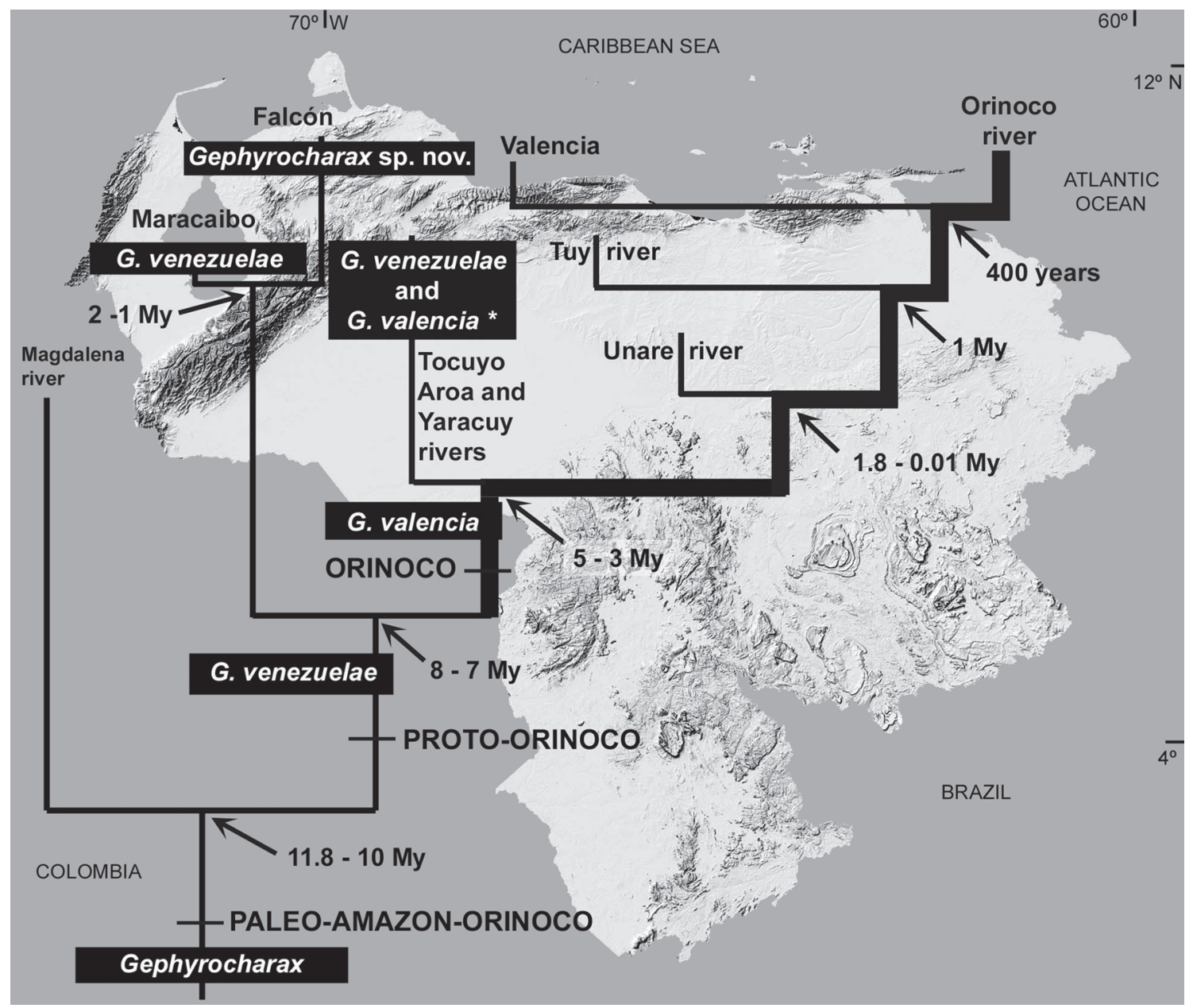

Fig. 3. Scheme for the possible origin of the species of Gephyrocharax in Venezuela. Hypothesized changes in the course of the Orinoco River in Venezuela and how they may have influenced the formation of major watersheds within the country follow Rod (1981), Díaz de Gamero (1996), and Lundberg et al. (1998). Major river basins in Venezuela are depicted in Fig. 1. (*) indicates simpatry.

result in the Orinoco River draining into the current eastcentral Llanos region, with connections to Venezuela's eastern Caribe (current Unare River basin, mainly) and Lake Valencia basins (Yoris \& Ostos, 1997; Hung, 2005). The species G. valencia probably originated through allopatric speciation after this last major course change and then dispersed into rivers located between the Andes and Cordillera de la Costa, the only localities where G. venezuelae and $G$. valencia occur in sympatry.

The geographical distribution and isoenzymatic relationships of Gephyrocharax valencia are consistent with the geomorphological facts described above. The current distribution of this species includes Venezuela's Caribe basin (western region in the Depression occupied by the Aroa, Tocuyo, Yaracuy, and Urama rivers, and eastern region with the Tuy, Guapo, Unare, and Neverí river basins), the Valencia Lake basin and Orinoco River basin. The current Neverí and Manzanares rivers in northeastern Venezuela could have been drainages (or portions thereof) already existing in the eastern inner Cordillera flowing south-north at least since the Pliocene, period which accounts for the late orogenesis in most of the country (Hung, 2005). It is probable that channels of the Orinoco in their eastward movement captured the courses of various drainages of the eastern inner Cordillera (north and south flanks), which could explain the presence of Gephyrocharax in the Neverí and Manzanares rivers. The above mentioned events could also explain the current geographic distribution of Corynopoma riisei, a monospecific genus used as external group for the genetic analysis in this study. C. riise i is also present in Venezuela's Orinoco, Caribe (Tuy and Manzanares rivers), and Lake Valencia (La Cumaca and San Diego rivers) basins as well as in Colombia (Meta River and Colombia's Orinoco basin) and the island of Trinidad.

The genus Gephyrocharax should be of at least Middle Miocene age consistent with the drainage of the late Paleo- 
Orinoco-Amazon in northwestern South America. The combined analysis of morphological and genetic information for this group along with biogeographic evidence, points toward a process of speciation with morphological stasis (Larson, 1989; Lundberg et al., 1986). In Venezuela there seem to be three genetically distinct lineages that maintain very little differences in body shape.

Based on the results for the three species of Gephyrocharax in Venezuela, we propose that the dominant process in the diversification and distribution of the current Venezuelan continental ichthyofauna appears to be associated with changes in the course of the Orinoco River, whose basin represents $70.5 \%$ of the national territory (Mago-Leccia, 1970). We suggest that the freshwater fishes of Lake Maracaibo and the Venezuelan western Caribe region had a vicariant origin from those of the Paleo-Orinoco-Amazon. Older and more complex processes such as the formation of paleoarchs and marine incursions and regressions (Hubert \& Renno, 2006) could explain the conformation of ichthyic regions in MaracaiboFalcón and the northern slopes of the Cordillera de la Costa. The regions and ichthyofauna most closely related should correspond to Venezuela's eastern Caribe and Orinoco basins, since they have been most recently connected.

Due to the wide range of palaeogeographic processes associated with the origin and distribution of the continental fishes of South America in general (Hubert \& Renno, 2006) and those of Venezuela in particular, it is important to carry out studies that incorporate morphological, genetic, and geomorphological aspects in order to answer questions about the processes that have led to the different taxa and to understand the possible factors that have shaped the distribution patterns of current freshwater fishes.

\section{Acknowledgments}

The authors wish to express their thanks to Universidad Central de Venezuela's Consejo de Desarrollo Científico y Humanístico (CDCH-UCV) for financing this research project identified by the code 03-31-3451/99. Antonio Machado provided comments on the manuscript and fish specimens from Río Pao. John Lundberg gave much advice on the final version of the manuscript. Thanks are also given to Valeska López who reviewed the English version of the manuscript.

\section{Literature Cited}

Aebersold, P. B., G. A. Winans, D. J. Teel, G. B. Milner \& F. M. Utter. 1987. Manual for starch gel electrophoresis: A method for the detection of genetic variation. National Oceanic and Atmospheric Administration Technical Report, National Marine Fisheries Service No. 61.

Albert, J., N. R. Lovejoy \& W. G. R. Crampton. 2006. Miocene tectonism and the separation of cis- and trans-Andean river basins: Evidence from Neotropical shes. Journal of South American Earth Science, 21:14-27.

Avise, J. C., C. A. Reeb \& N. C. Saunders. 1987. Geographic population structure and species differences in mitochondrial
DNA of mouthbrooding marine catfishes Batrachoididae. Evolution, 41: 991-1002.

Bonilla, A. \& H. López. 2001. Diferenciación morfológica cuantitativa de las especies del género Gephyrocharax Eigenmann 1912 (Pisces: Characidae: Glandulocaudinae) de Venezuela. Acta Biologica Venezuelica, 21: 1-10.

Bonilla, A., H. López \& A. Machado. 2002. Especiación vicariante en el género Gephyrocharax Eigenmann 1912 (Pisces: Characidae: Glandulocaudinae) de Venezuela. Interciencia, 27: 118-127.

Bush, G. L. 1975. Modes of animal speciation. Annual Review of Ecology and Systematics, 6: 339-364.

Buth, D. G. \& R. W. Murphy. 1990. Enzyme staining formulas. Pp. 99-126. In: Hillis, D. M. \& C. Moritz (Eds.). Molecular Systematics. Sinauer Associates, Inc.

Carmona, J. A., J. Domínguez \& I. Doadrio. 2000. Congruence between allozyme and cytochrome $b$ gene sequence data in assessing genetic differentiation within the Iberian endemic Chondrostoma lemmingii (Pisces: Cyprinidae). Heredity, 84: 721-732.

Dahl, G. 1971. Los peces del norte de Colombia. Ministerio de Agricultura, Inderena.

Díaz de Gamero, M. L. 1996. The changing course of the Orinoco River during the Neogene: a review. Palaeogeography, Palaeoclimatology, Palaeoecology, 123: 385-402.

Dimmick, W. W. \& R. Lawson. 1991. Phylogenetic relationships of members of the genus Pteronotropis inferred from parsimony analysis of allozymic and morphological data (Cyprinidae: Cypriniformes). Biochemical Systematics and Ecology, 19: 413419.

Eigenmann, C. H. 1912. Some results from an ichthyological reconnaissance of Colombia, South America. Indiana University Studies, 16: 1-27.

Hubert, N. \& J. F. Renno. 2006. Historical biogeography of South American freshwater fishes. Journal of Biogeography, 33: 14141436.

Hung, E. J. 2005. Thrust belt interpretation of the Serranía del Interior and Maturín subbasin, eastern Venezuela, Pp. 251-270. In: Ave Lallemant, H. G. \& V. B. Sisson (Eds.). Caribbean-South American plate interactions, Venezuela. Special Paper of the Geological Society of America.

Johnson, J. B. 2001. Hierarchical organization of genetic variation of the Costa Rican livebearing fish Brachyrhaphis rhabdophora (Poeciliidae). Biological Journal of the Linnean Society, 72: 519527.

Kimura, M. \& G. H. Weiss. 1964. The stepping stone model of population structure and the decrease of genetic correlation with distance. Genetics, 49: 561-576.

Larson, A. 1989. The relationship between speciation and morphological evolution. Pp. 579-598. In: Otte, D. \& J. A. Endler, (Eds.). Speciation and its consequences. Sinauer Associates, Inc.

López, H., C. Marcano \& O. Brull. 1996. Los peces del refugio de Fauna Silvestre Cuare (Falcón) y zonas adyacentes. Acta Biologica Venezuelica, 16: 27-34.

Lovejoy, N. R., J. S. Albert \& W. G. R Crampton. 2006. Miocene marine incursions and marine/freshwater transitions: Evidence from Neotropical fishes. Journal of South American Earth Science, 21: 5-13.

Lovejoy, N. R., E. Bermingham \& A. P. Martin. 1998. Marine incursion into South America. Nature, 396: 421-422.

Lowe-McConnell, R. H. 1969. Speciation in tropical freshwater fishes. Biological Journal of the Linnean Society, 1: 51-75. 
Lundberg, J. G., A. Machado \& R. F. Kay. 1986. Miocene characid fishes from Colombia: evidence for evolutionary stasis and extirpation in the South American ichthyofauna. Science, 234: 208-209.

Lundberg, J. G., L. G. Marshall, J. Guerrero, B. Horton, M. C. Malabarba \& F. Wesseling. 1998. The stage for neotropical fish diversification: A history of tropical South American rivers, Pp. 13-48. In: Malabarba, L. R., R. E. Reis, R. P. Vari, Z. M. Lucena, C. A. S. Lucena (Eds.). Phylogeny and Classification of Neotropical Fishes. Porto Alegre, Edipucrs.

Mago-Leccia, F. 1970. Lista de los peces de Venezuela. Ministerio de Agricultura y Cría. Caracas.

McKay, S. I. \& P. J. Miller. 1991. Isozyme criteria in the testing of phyletic relationship between species of Gobius and related eastern Atlantic-Mediterranean genera (Teleostei: Gobiidae). Journal of Fish Biology, 39: 291-299.

Méndez, O. 1985. Historia geológica graficada de la Cuenca Oriental de Venezuela. VI Congreso Geológico Venezolano, 6: 10001040.

Morris, M. R., K. de Queiroz \& D. C. Morizot. 2001. Phylogenetic relationships among populations of northern swordtails (Xiphophorus) as inferred from allozyme data. Copeia, 2001: 65-81.

Murphy, R. W., J. W. Sites Jr., D. G. Buth \& C. H. Haufler. 1990. Protein I: Isoenzyme Electrophoresis. Pp. 45-126. In: Hillis, D. M. \& C. Moritz (Eds.). Molecular Systematics. Sinauer Associates, Inc..

Nei, M. 1975. Molecular population genetics and evolution. NorthHolland Publising Company.

PDVSA. 2008. Código Estratigráfico de las Cuencas Petroleras de Venezuela. Intevep, Comité Interfilial de Estratigrafía y Nomenclatura.available at: www.pdvsa.com/lexico/index.html.

Pouyaud, L., G. G. Teugels, R. Gustiniano \& L. Legendre. 2000. Contribution to the phylogeny of pangasiid catfishes based on allozymes and mitochondrial DNA. Journal of Fish Biology, 56: 1509-1538.

Revaldaves, E., E. Renesto \& M. Machado. 1997. Genetic variability of Prochilodus lineatus (Characiformes, Prochilodontidae) in the upper Paraná River. Brazilian Journal of Genetics, 20: 381388.

Rod, E. 1981. Notes on the shifting course of the ancient Rio Orinoco from late Cretaceous to Oligocene time. Geos, 26: 54-56.

Rodríguez, D., A. Amaro, J. Coronel \& D. Taphorn. 2006. Los peces del río Aroa, cuenca del Caribe, Venezuela. Memoria de la Fundación La Salle de Ciencias Naturales, 164: 101-127.

Rogers, J. S. 1986. Deriving phylogenetic trees from allele frequencies: a comparison of nine genetic distances. Systematic Biology, 35: 297-310.

Salzburger, W., T. Mack, E. Verheyen \& A. Meyer. 2005. Out of Tanganyika: genesis, explosive speciation, key-innovations and phylogeography of the haplochromine cichlid fishes. BMC Evolutionary Biology, 5: 17-18.
Schultz, L. P. 1944. The fishes of the family Characinidae from Venezuela, with descriptions of seventeen new forms. Proceeding of the United States National Museum, 95: 235-367.

Shaklee, J. B., F. W. Allendorf, D. C. Morizot \& G. S. Whitt. 1990. Gene nomenclature for protein-coding loci in fish. Transactions of the American Fisheries Society, 119: 2-15.

Slatkin, M. 1985. Gene flow in natural populations. Annual Review of Ecology and Systematics, 16: 393-430.

Strecker, U., V. H. Faúndez \& H. Wilkens. 2004. Phylogeography of surface and cave Astyanax (Teleostei) from Central and North America based on cytochrome $b$ sequence data. Molecular Phylogenetics and Evolution, 33: 469-481.

Swofford, D. L. \& R. B. Selander. 1981. BIOSYS-1: a FORTRAN program for the comprehensive analysis of electrophoretic data in population genetics and systematics. Journal of Heredity, 72: 281-283.

Taphorn, D. C. \& C. G. Lilyestrom. 1984. Clave para los peces de agua dulce de Venezuela. Revista Unellez de Ciencia y Tecnología, 2: 5-30.

Trexler, J. C. 1988. Hierarchical organization of genetic variation in the sailfin molly, Poecilia latipinna (Pisces: Poecilidae). Evolution, 42: 1006-1017.

Wang, J. P., H. D. Lin, S. Huang, C. H. Pan, X. L. Chen \& T. Y. Chiang. 2004. Phylogeography of Varicorhinus barbatulus (Cyprinidae) in Taiwan based on nucleotide variation of mtDNA and allozymes. Molecular Phylogenetics and Evolution, 31: 1143-1156.

Weitzman, S. H. \& N. Menezes. 1998. Relationships of the Tribes and Genera of the Glandulocaudinae (Ostariophysi: Characiformes: Characidae) with a description of a new Genus, Chrysobrycon. Pp. 171-192. In: Malabarba, L. R., R. E. Reis, R. P. Vari, Z. M. Lucena, C. A. S. Lucena (Eds.). Phylogeny and Classification of Neotropical Fishes. Porto Alegre, Edipucrs.

Weitzman, S. H., N. A. Menezes, H. G. Evers \& J. R. Burns. 2005. Putative relationships among inseminating and externally fertilizing characids, with a description of a new genus and species of Brazilian inseminating fish bearing an anal-fin gland in males (Characiformes: Characidae). Neotropical Ichthyology, 3: 329-360.

Wright, S. 1931. Evolution in mendelian populations. Genetics, 16: 97-159.

Wright, S. 1943. Isolation by distance. Genetics, 28: 114-138.

Wright, S. 1978. Evolution and Genetics of Populations Vol. 4. Variability within and among natural populations. University of Chicago Press, Chicago.

Yoris, F. \& M. Ostos. 1997. Geología de Venezuela. Pp. 1-17. In: J. Singer (Ed.). $1^{\text {ra }}$. Ed. Español, Geología General y Cuencas Petrolíferas, Conferencia Evaluación de Pozos. SchlumbergerSurenco, C.A. Jolley Printing (Texas).

Submitted May 4, 2013 Accepted June 14, 2013 by Claudio Oliveira Published September 30, 2013 